\title{
Original Article \\ Ethanolic Extract of Propolis Augments TRAIL-Induced Apoptotic Death in Prostate Cancer Cells
}

\author{
Ewelina Szliszka, ${ }^{1}$ Zenon P. Czuba, ${ }^{1}$ Joanna Bronikowska, ${ }^{1}$ Anna Mertas, ${ }^{1}$ Andrzej Paradysz, ${ }^{2}$ \\ and Wojciech Krol ${ }^{1}$ \\ ${ }^{1}$ Chair and Department of Microbiology and Immunology, Jordana 19, 41808 Zabrze, Poland \\ ${ }^{2}$ Chair and Department of Urology, 3-go Maja 13, 41800 Zabrze, Medical University of Silesia in Katowice, Poland
}

Correspondence should be addressed to Wojciech Krol, wkrol@sum.edu.pl

Received 28 February 2009; Accepted 6 October 2009

Copyright (C) 2011 Ewelina Szliszka et al. This is an open access article distributed under the Creative Commons Attribution License, which permits unrestricted use, distribution, and reproduction in any medium, provided the original work is properly cited.

\begin{abstract}
Prostate cancer is a commonly diagnosed cancer in men. The ethanolic extract of propolis (EEP) and its phenolic compounds possess immunomodulatory, chemopreventive and antitumor effects. Tumor necrosis factor-related apoptosis-inducing ligand (TRAIL/APO2L) is a naturally occurring anticancer agent that preferentially induces apoptosis in cancer cells and is not toxic to normal cells. We examined the cytotoxic and apoptotic effects of EEP and phenolic compounds isolated from propolis in combination with TRAIL on two prostate cancer cell lines, hormone-sensitivity LNCaP and hormone-refractory DU145. The cytotoxicity was evaluated by MTT and LDH assays. The apoptosis was determined using flow cytometry with annexin VFITC/propidium iodide. The prostate cancer cell lines were proved to be resistant to TRAIL-induced apoptosis. Our study demonstrated that EEP and its components significantly sensitize to TRAIL-induced death in prostate cancer cells. The percentage of the apoptotic cells after cotreatment with $50 \mu \mathrm{g} \mathrm{mL} \mathrm{m}^{-1} \mathrm{EEP}$ and $100 \mathrm{ng} \mathrm{mL}{ }^{-1}$ TRAIL increased to $74.9 \pm 0.7 \%$ for LNCaP and 57.4 $\pm 0.7 \%$ for DU145 cells. The strongest cytotoxic effect on LNCaP cells was exhibited by apigenin, kaempferid, galangin and caffeic acid phenylethyl ester (CAPE) in combination with TRAIL $(53.51 \pm 0.68-66.06 \pm 0.62 \%$ death cells). In this work, we showed that EEP markedly augmented TRAIL-mediated apoptosis in prostate cancer cells and suggested the significant role of propolis in chemoprevention of prostate cancer.
\end{abstract}

\section{Introduction}

Prostate cancer is a commonly diagnosed cancer in men, and it is the second leading cause of death due to cancer in men in the European Union and in the USA. The rate of prostate cancer among all new cancer cases has been estimated at $12 \%$ in the EU and $29 \%$ in the USA. The molecular mechanisms responsible for the initiation and progression of prostate cancer have not been elucidated, and the only established risk factors for this disease include age, ethnic group, diet and hereditary susceptibility [1]. Prostate cancer behavior is mostly unpredictable; however, its longer time of progression to malignancy and metastasis provides broader possibilities for its managements, including the suitability for chemopreventive intervention. Chemoprevention is a rapidly growing area of uro-oncology, which focuses on prevention of prostate cancer using naturally occurring or synthetic agents [2, 3]. Many plant and animal extracts show various biological activities, such as immunopotentiating and antitumor properties [4-6].

Propolis (bee glue) is a resinous hive product collected by honey bees from many plant sources. Propolis usually contains a variety of different chemical compounds, including phenolic acids or their esters, flavonoids (flavones, flavanones, flavonols, dihydroflavonols and chalcones), terpenes, aromatic aldehydes and alcohols, fatty acids, stilbenes and $\beta$-steroids $[7,8]$. Propolis cannot be used in its crude form, and so it must be purified by extraction to remove the inert material and preserve the polyphenolic fraction. The ethanolic extract of propolis (EEP) has attracted researchers' interest in the last decades because of its biological and pharmacological properties, such as immunomodulatory and anticancer effects [9-11]. Several mechanisms contribute to the overall cancer preventive and antitumor properties of propolis and its phenolic components. Further study demonstrated that flavonoids, phenolic acids, as well as EEP 
inhibit the cancer cells proliferation and tumor growth, induce cell-cycle arrest and apoptosis [10-14].

The target of much research has been on discovery of natural and synthetic compounds that can be used in the prevention of cancer. Epidemiological and preclinical evidence suggest that polyphenols isolated from propolis possess cancer chemopreventive properties [12]. Due to the fact that propolis is a rich source of plant phenolics and polyphenolics, it can be used as a dietary supplement in prostate cancer prevention.

The role of host immune functions has become increasingly important in our understanding of the mechanisms involved in cancer prevention. EEP stimulated nonspecific immunity, activated humoral immunity, and enhanced cellmediated immunity $[10,15]$. The increase of the host immune defence by propolis against tumor cells suggests that immunomodulatory effects of EEP may be involved in cancer chemoprevention.

Tumor necrosis factor-related apoptosis inducing ligand (TRAIL), a member of TNF superfamily, selectively induces apoptosis in cancer cells with no toxicity against normal tissues. Soluble, or expressed on lymphocytes $\mathrm{T}$, macrophages and NK cells molecules, TRAIL plays an important role in immune surveillance and defence mechanisms against tumor cells. The cytotoxic effector functions of those immune cells are important for enabling the immune system to cope efficiently with malignancy. TRAIL induces programed death in various cancer cells through its interaction with the death receptor TRAIL-R1 and/or TRAIL-R2 [16].

However, some tumor cells are resistant to TRAILmediated cytotoxicity. The decreased expression of death receptors TRAIL-R1 and TRAIL-R2 or increased expression of antiapoptotic protein in cancer cells are involved in TRAIL-resistance. We and others have shown that TRAILresistant prostate cancer cells can be sensitized by chemotherapeutic agents, ionizing radiation, or dietary polyphenols [17-19].

In this work, we investigated the apoptotic and/or cytotoxic effect of EEP and some of its phenolic derivatives in combination with TRAIL on prostate cancer cells. We showed for the first time that EEP sensitizes prostate cancer cells to TRAIL-induced apoptosis. Our results indicated that EEP markedly augments TRAIL-mediated apoptosis in hormone-sensitivity $\mathrm{LNCaP}$ and hormone-refractory DU145 prostate cancer cells. The TRAIL-mediated cytotoxic and apoptotic pathways may be a target of the chemopreventive agents in prostate cancer cells, and the overcome of TRAIL-resistance by propolis and its phenolic components may be one of the mechanisms responsible for their cancer preventive effects.

\section{Methods}

2.1. Propolis Sample and EEP. Propolis was collected manually from beehives located in southern Poland (The Carpathians, Nowy Sacz region) and kept desiccated pending its processing. It was extracted in $95 \%(\mathrm{v} / \mathrm{v})$ ethyl alcohol, in a hermetically closed glass vessel for 4 days at $37^{\circ} \mathrm{C}$, under occasional shaking. The ethanolic extract was then filtered through a Whatman filter paper no 4 and evaporated in a rotary evaporator, under reduced pressure at $60^{\circ} \mathrm{C}$. The same collection and extraction procedures were used throughout all our laboratory studies [9]. EEP was dissolved in DMSO (50 $\mathrm{mg} \mathrm{mL}^{-1}$ ), and the final concentration of DMSO in the culture medium was controlled at $0.1 \%(\mathrm{v} / \mathrm{v})$.

2.2. Flavonoids and Phenolic Acids. Propolis samples from various geographical areas contain different compounds. The major active components of propolis from Poland are flavonoids and phenolic acids or their esters [7]. All tested compounds were detected in our sample of EEP as described previously [9]. Table 1 presents the structures of compounds found in the tested sample of EEP. Chrysin, apigenin, acacetin, galangin, kaempferol, kaempferid, quercetin, cinnanic acid, $o$-coumaric acid, $m$-coumaric acid, $p$-coumaric acid, caffeic acid and caffeic acid phenylethyl ester (CAPE) were purchased from Carl Roth GmbH (Karlsruhe, Germany) and Sigma Chemical Company (St Louis, MO, USA). The reagents were dissolved in DMSO (flavonoids and phenolic acids- $50 \mathrm{mM}$ ) and the final concentration of DMSO in the culture medium was controlled at $0.1 \%(\mathrm{v} / \mathrm{v})$. The final concentration of flavonoids and phenolic acids was $50 \mu \mathrm{M}$ (chrysin, $12.7 \mu \mathrm{g} \mathrm{mL}^{-1}$; apigenin, $13.5 \mu \mathrm{g} \mathrm{mL}^{-1}$; acacetin, $14.2 \mu \mathrm{g} \mathrm{mL}^{-1}$; galangin, $13.5 \mu \mathrm{g} \mathrm{mL}^{-1}$; kaempferol, $14.3 \mu \mathrm{g}$ $\mathrm{mL}^{-1}$; kaempferid, $15.0 \mu \mathrm{g} \mathrm{mL}^{-1}$; quercetin, $15.1 \mu \mathrm{g} \mathrm{mL}^{-1}$; cinnanic acid, $7.4 \mu \mathrm{g} \mathrm{mL}^{-1}$; $o$-coumaric acid, $8.2 \mu \mathrm{g} \mathrm{mL}^{-1} ; m$ coumaric acid, $8.2 \mu \mathrm{g} \mathrm{mL}^{-1}$; $p$-coumaric acid, $8.2 \mu \mathrm{g} \mathrm{mL}^{-1}$; caffeic acid, $9.0 \mu \mathrm{g} \mathrm{mL}^{-1}$; CAPE, $14.2 \mu \mathrm{g} \mathrm{mL}^{-1}$ ).

2.3. TRAIL. Recombinant human TRAIL was purchased from PeproTech (Rocky Hill, NJ, USA).

2.4. Prostate Cancer Cells Culture. The experiments were performed on two human prostate cancer cell lines: hormonesensitivity LNCaP cells and hormone-refractory DU145 cells (DSMZ-German Collection of Microorganisms and Cell Cultures, Braunschweig, Germany). The cells were grown in monolayer cultures in RPMI 1640 medium containing $10 \%$ fetal bovine serum, $4 \mathrm{mM}$ L-glutamine, $100 \mathrm{U} \mathrm{mL}^{-1}$ penicillin and $100 \mu \mathrm{g} \mathrm{mL}^{-1}$ streptomycin and incubated at $37^{\circ} \mathrm{C}$ in atmosphere containing $5 \% \mathrm{CO}_{2}$ [19]. Reagents for cells culture were purchased from PAA The Cell Culture Company (Pasching, Austria).

2.5. Cytotoxicity Assay. The cytotoxicity was measured by 3[4, 5-dimethylthiazol-2-yl]-2,5 diphenyltetrazolium (MTT) assay as described [19]. The LNCaP cells $\left(2 \times 10^{5} \mathrm{~mL}^{-1}\right)$ and DU145 $\left(1 \times 10^{5} \mathrm{~mL}^{-1}\right)$ were seeded $48-24 \mathrm{~h}$ before the experiments onto a 96-well plate. Various combinations of EEP (5-50 ng mL $\mathrm{mL}^{-1}$ ) with or without TRAIL (50$\left.200 \mathrm{ng} \mathrm{mL}^{-1}\right)$, flavonoids $(50 \mu \mathrm{M})$ with or without TRAIL (100 $\left.\mathrm{ng} \mathrm{mL}^{-1}\right)$, and phenolic acids $(50 \mu \mathrm{M})$ with or without TRAIL ( $100 \mathrm{ng} \mathrm{mL}^{-1}$ ) were added to the cells, and, after $48 \mathrm{~h}$, the medium was removed, and $20 \mu \mathrm{L}$ of a MTT solution prepared at $5 \mathrm{mg} \mathrm{mL}^{-1}$ (Sigma Chemical Company, MO, USA) were added to each well for $4 \mathrm{~h}$. The resulting crystals 
Cinnamic acid

$o$-Coumaric acid

$m$-Coumaric acid

p-Coumaric acid

Caffeic acid

Caffeic acid phenylethyl ester<smiles>[R]c1ccc(/C=C/C(=O)O)c([R])c1[R]</smiles>

$\begin{array}{ccc}\mathrm{R}_{1} & \mathrm{R}_{2} & \mathrm{R}_{3} \\ \mathrm{H} & \mathrm{H} & \mathrm{H} \\ \mathrm{OH} & \mathrm{H} & \mathrm{H} \\ \mathrm{H} & \mathrm{OH} & \mathrm{H} \\ \mathrm{H} & \mathrm{H} & \mathrm{OH} \\ \mathrm{H} & \mathrm{OH} & \mathrm{OH}\end{array}$

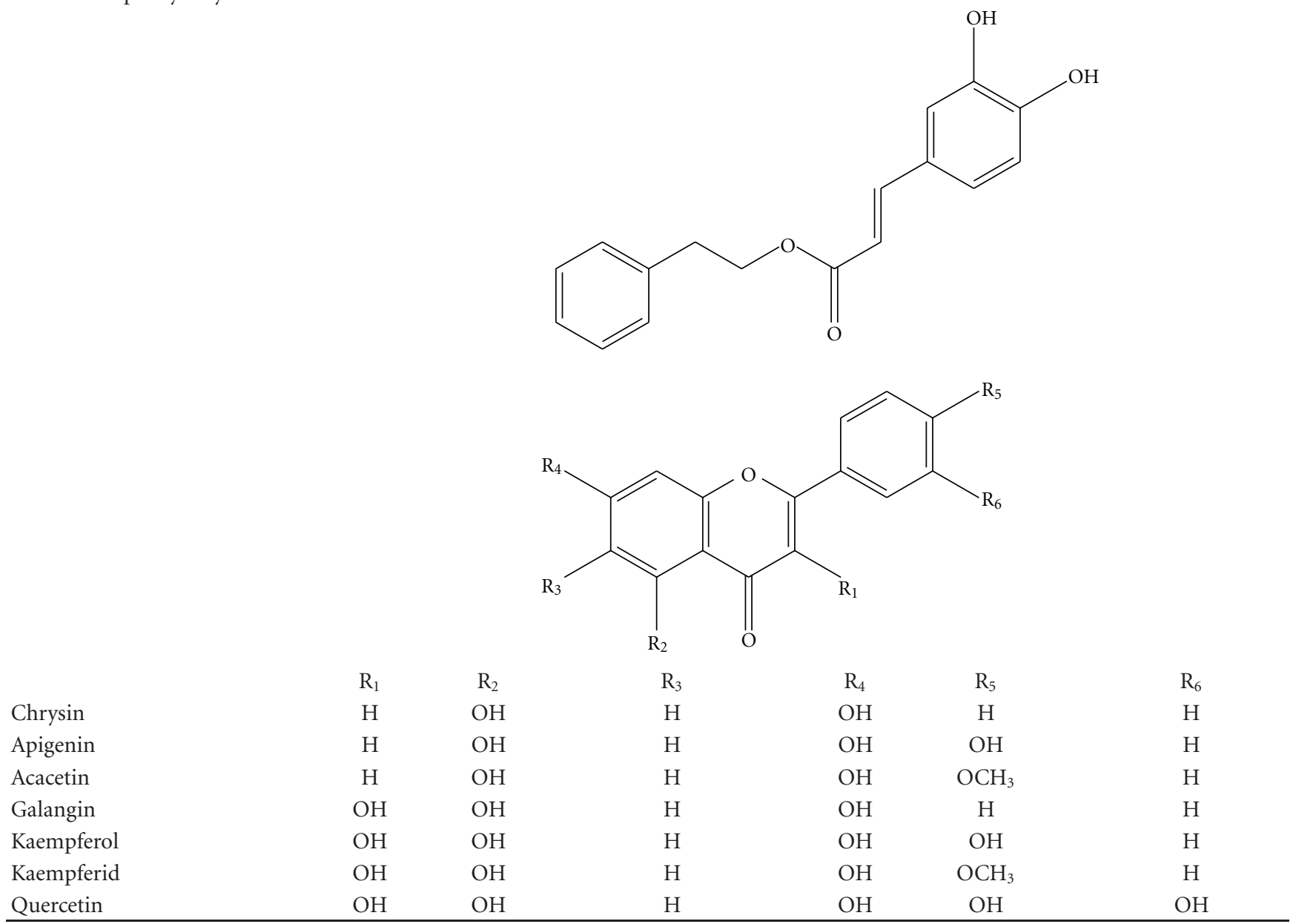

were dissolved in DMSO. Controls included native cells and medium alone. The spectrophotometric absorbance of each well was measured using a microplate reader (ELx 800, Bio-Tek Instruments, Winooski, VT, USA) at $550 \mathrm{~nm}$. The percent cytotoxicity was calculated by the formula: percent cytotoxicity $($ cell death $)=(1-[$ absorbance of experimental wells/absorbance of control wells] $) \times 100 \%$.

2.6. Lactate Dehydrogenase Release Assay. Lactate dehydrogenase $(\mathrm{LDH})$ is a stable cytosolic enzyme that is released 


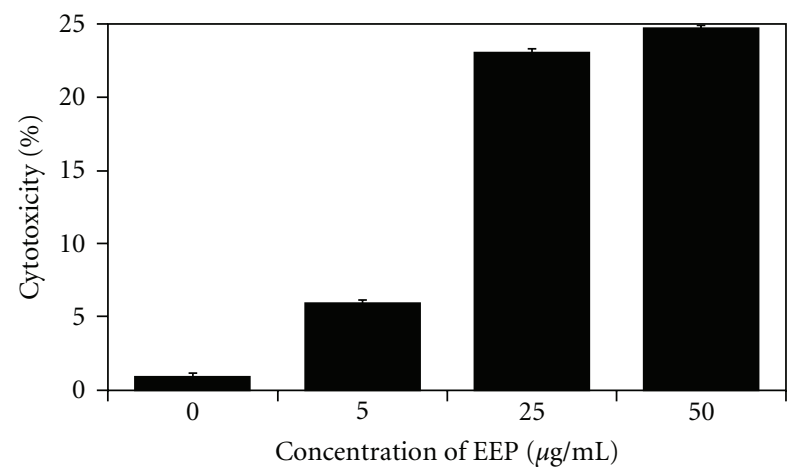

(a)

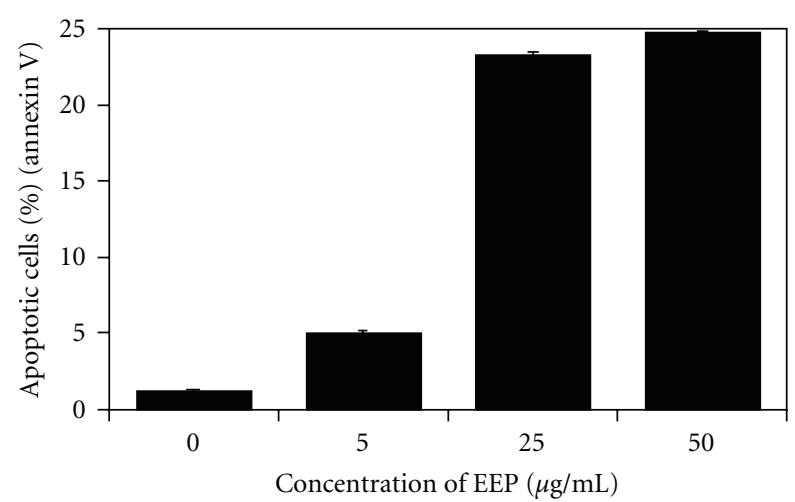

(c)

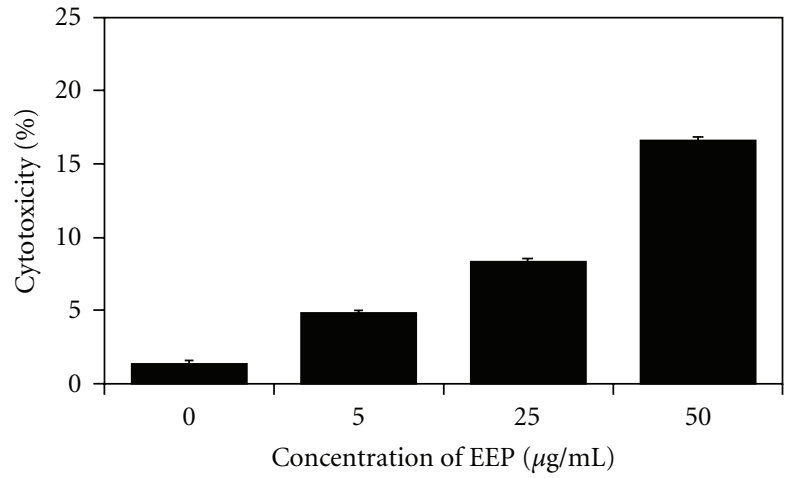

(b)

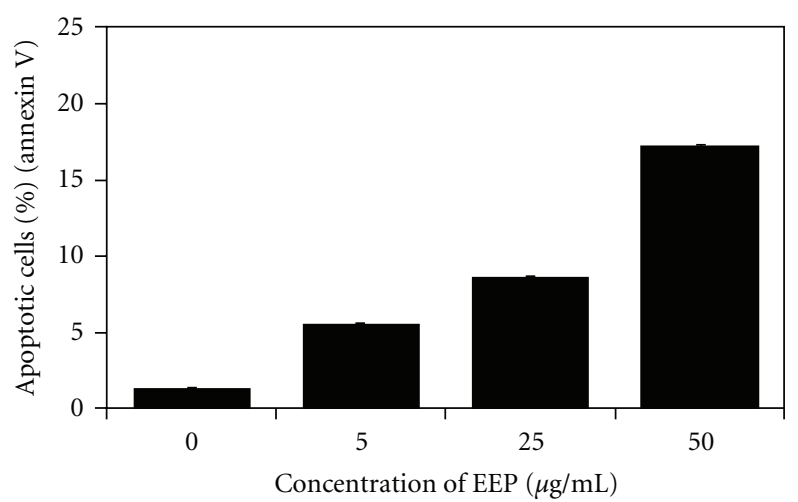

(d)

FIGURE 1: Induction of cytotoxicity and apoptosis by EEP in prostate cancer cells. The cells were incubated for $48 \mathrm{~h}$ with EEP at concentrations of $0-50 \mu \mathrm{g} \mathrm{mL}^{-1}$. Cytotoxic activity of EEP in prostate cancer cells: (a) LNCaP and (b) DU145. The percentage of cell deaths was measured by MTT cytotoxicity assay. EEP induced apoptosis in prostate cancer cells: (c) LNCaP and (d) DU145. Detection of apoptotic cell death by annexin V-FITC staining using flow cytometry. The values represent mean \pm SD of three independent experiments performed in quadruplicate $(n=12)$. All differences are statistically significant in relation to control $(P<.05)$.

upon membrane damage in necrotic cells. LDH activity was measured using a commercial cytotoxicity assay kit (Roche Diagnostics GmbH, Mannheim, Germany), in which LDH released in culture supernatants is measured with a coupled enzymatic assay, resulting in conversion of a tetrazolium salt into red formazan product. The prostate cancer cells were treated with EEP in various concentrations $\left(5-50 \mathrm{ng} \mathrm{mL}^{-1}\right)$ alone and in combination with TRAIL (50-200 $\mathrm{ng} \mathrm{mL}^{-1}$ ), phenolic compounds $(50 \mu \mathrm{M})$ alone and in combination with TRAIL $\left(100 \mathrm{ng} \mathrm{mL}^{-1}\right)$ for the indicated period of time. The sample solution (supernatant) was removed, and LDH released from cells was measured in culture medium. The maximal release was obtained after treating control cells with 1\% Triton X-100 (Sigma Chemical Company, St. Louis, MO) for $10 \mathrm{~min}$ at room temperature [19]. The necrotic percentage was expressed using the formula (sample value/maximal release) $\times 100 \%$. $V$-FITC Staining. Prostate cancer cell line $\operatorname{LNCaP}(2 \times$ $\left.10^{5} \mathrm{~mL}^{-1}\right)$ and DU145 $\left(1 \times 10^{5} \mathrm{~mL}^{-1}\right)$ were seeded in 24 -well plates for 24-48 h and then exposed to EEP and/or TRAIL for $48 \mathrm{~h}$. After 48 -h incubation, cancer cells were washed twice with PBS and resuspended in $1 \mathrm{~mL}$ of binding buffer. Five hundred microliters of cell suspension were then incubated with $5 \mu \mathrm{L}$ of annexin V-FITC and $10 \mu \mathrm{L}$ of propidium iodide (PI) for $10 \mathrm{~min}$ at room temperature in the dark. Annexin V assay was performed using the Apoptotest-FITC Kit (Dako, Glostrup, Denmark). The population of annexin V-positive cells was evaluated by flow cytometry (BD FACScan, Becton Dickinson Immnunocytometry Systems, San Jose, CA, USA) [20].

2.8. Statistical Analysis. The results are expressed as mean \pm SD obtained from three separate experiments. The experimental means were compared to the means of untreated prostate cancer cells harvested parallelly, and the data were polled for replicate experiments. Statistical significance was evaluated using one- and multiple-way ANOVA or KruskalWallis test followed by the Levene post hoc test. $P$-values $<.05$ were considered significant. 


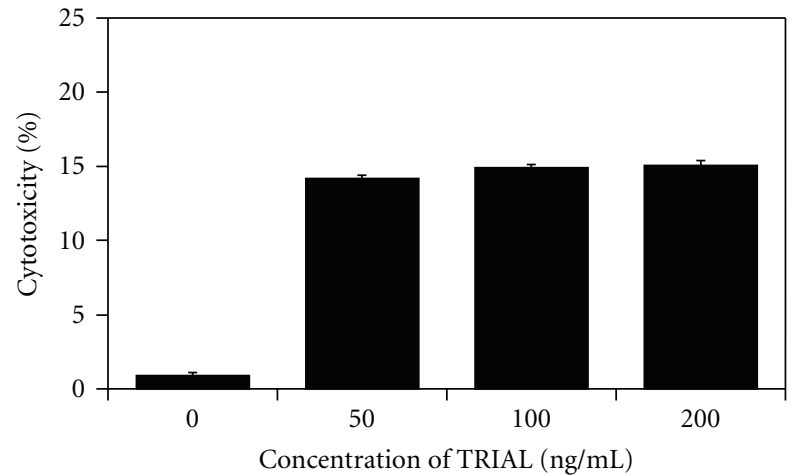

(a)

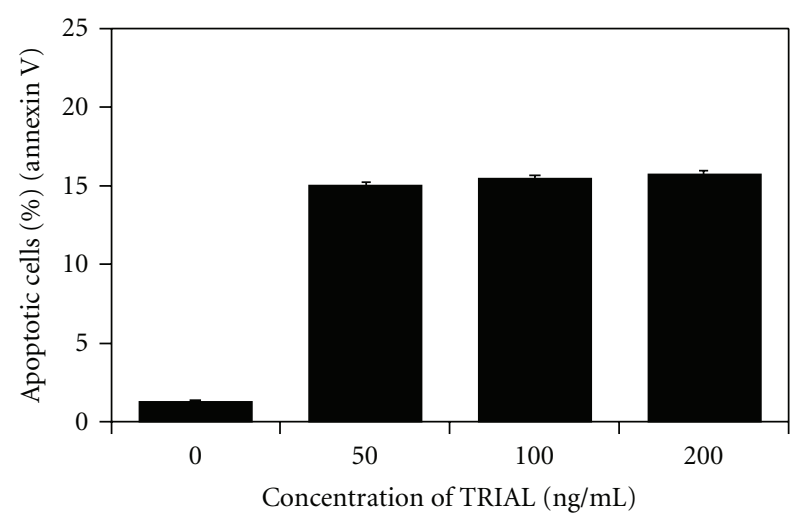

(c)

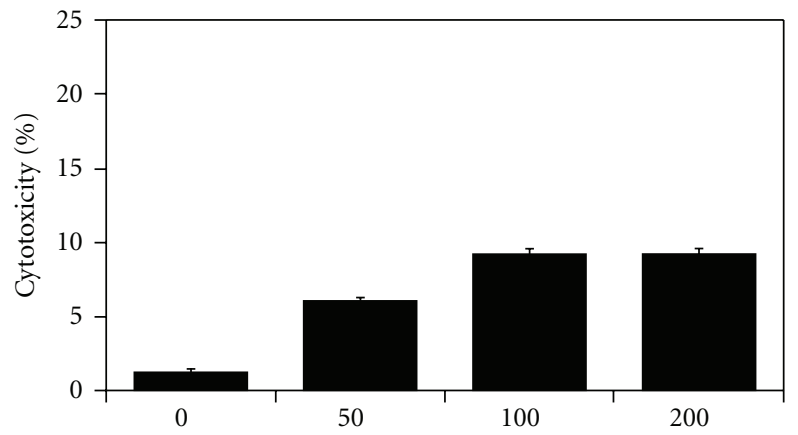

Concentration of TRIAL (ng/mL)

(b)

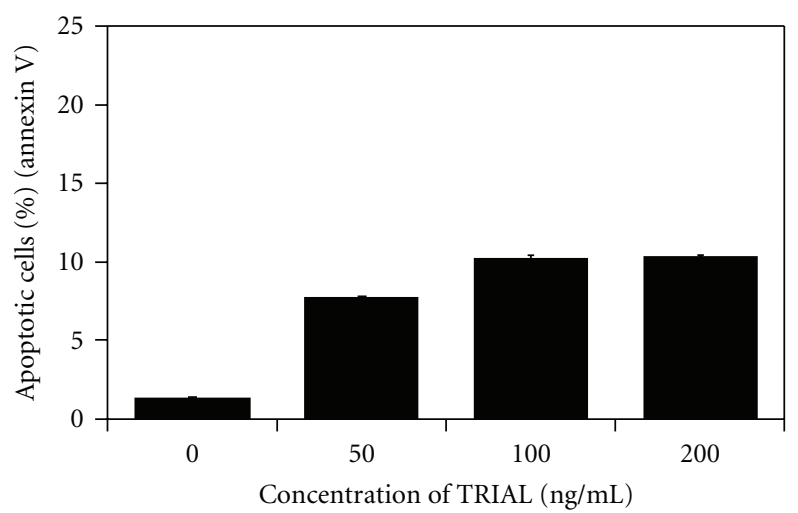

(d)

FIgURE 2: Induction of cytotoxicity and apoptosis by TRAIL in prostate cancer cells. The cells were incubated for $48 \mathrm{~h}$ with TRAIL at concentrations of $0-200 \mathrm{ng} \mathrm{mL}^{-1}$. Cytotoxic activity of TRAIL in prostate cancer cells: (a) LNCaP and (b) DU145. The percentage of cell deaths was measured by MTT cytotoxicity assay. TRAIL induced apoptosis in prostate cancer cells: (c) LNCaP and (d) DU145. Detection of apoptotic cell death by annexin V-FITC staining using flow cytometry. The values represent mean \pm SD of three independent experiments performed in quadruplicate $(n=12)$. All differences are statistically significant in relation to control $(P<.05)$.

\section{Results}

\subsection{Induction of Cytotoxicity and Apoptosis by Studied Agents on Prostate Cancer Cells}

3.1.1. EEP. EEP inhibited growth and induced apoptosis in prostate cancer cells in a dose-dependent manner. The cytotoxic and apoptotic effects of EEP on hormone-sensitivity LNCaP and hormone-refractory DU145 prostate cancer cells are given in Figure 1. The cells were incubated with 5$50 \mu \mathrm{g} \mathrm{mL}^{-1}$ EEP for $48 \mathrm{~h}$. The rate of cytotoxicity upon treatment cancer cells with 5,25 and $50 \mu \mathrm{g} \mathrm{mL}^{-1}$ EEP was $5.96 \pm 0.61,23.08 \pm 0.78$ and $24.83 \pm 0.59 \%$ for $\mathrm{LNCaP}$ cells and $4.75 \pm 0.67,8.20 \pm 1.12$ and $16.63 \pm 0.77 \%$ for DU145 when compared with untreated control, respectively. The annexin $\mathrm{V}$ assay revealed apoptotic prostate cancer cells exposed to EEP. We showed that EEP at the concentrations of $5-50 \mu \mathrm{g} \mathrm{mL}^{-1}$ induced $4.95 \pm 0.54,23.28 \pm 0.54$ and $24.66 \pm$ $0.72 \%$ apoptosis in LNCaP cells and $5.44 \pm 0.45,8.52 \pm 0.48$ and $17.09 \pm 0.55 \%$ apoptosis in DU145 cells.

3.1.2. TRAIL. TRAIL induced cytotoxic and apoptotic effects in a dose-dependent manner (Figure 2). We first measured the cytotoxic activity of TRAIL after 48-h incubation on prostate cancer cells. The cytotoxicity of TRAIL at the concentration of $100 \mathrm{ng} \mathrm{mL}^{-1}$ on LNCaP cells was $15.03 \pm$ $0.50 \%$, and on DU145 cells $9.25 \pm 0.86 \%$. TRAIL increased the percentage of apoptotic cells. For example, a 48 -h exposure to $100 \mathrm{ng} \mathrm{mL}^{-1}$ TRAIL induced apoptosis of 15.46 $\pm 0.55 \%$ LNCaP cells and $10.12 \pm 0.86 \%$ of DU145 cells. TRAIL was less active against the both prostate cancer cell lines. We confirmed that hormone-sensitivity LNCaP cells and hormone-refractory DU145 prostate cancer cells are resistant to TRAIL.

3.1.3. TRAIL in Combination with EEP. We investigated the cytotoxic and apoptotic effects of TRAIL in combination with EEP on prostate cancer cells (Figures 3 and 4). Cotreatment of TRAIL and EEP increased the percentage of cell death on prostate cancer cells, compared to cytotoxicity of TRAIL or EEP alone. The cytotoxicity after 48 -h incubation with TRAIL at the concentration of $100 \mathrm{ng} \mathrm{mL}^{-1}$, and EEP at the concentration of $50 \mu \mathrm{g} \mathrm{mL}^{-1}$ was $73.70 \pm 0.53 \%$ for hormone-sensitivity LNCaP cells and $55.76 \pm 0.72 \%$ for hormone-refractory DU145 cells. Then, we tested the apoptotic effect of TRAIL in combination with EEP on 


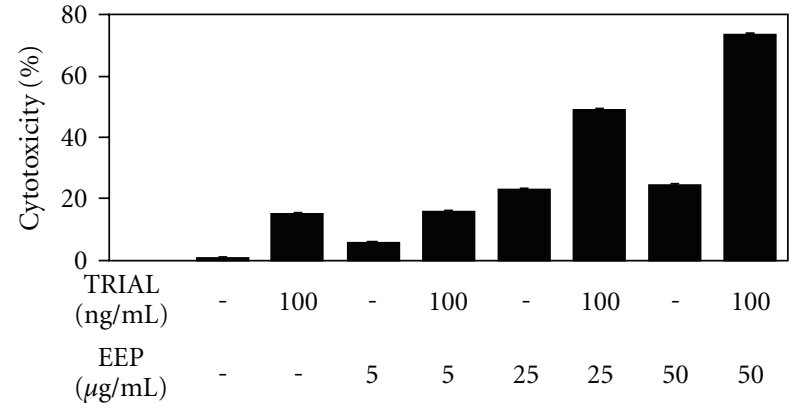

(a)

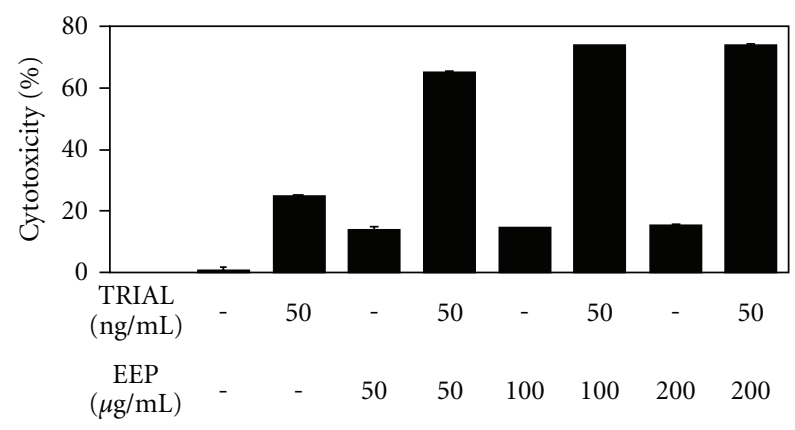

(c)

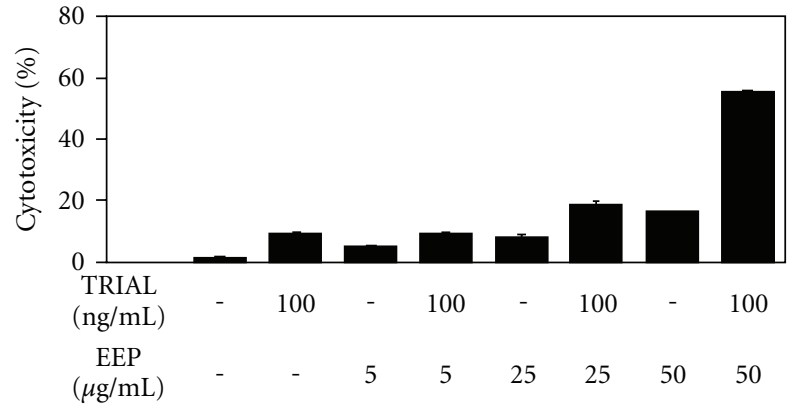

(b)

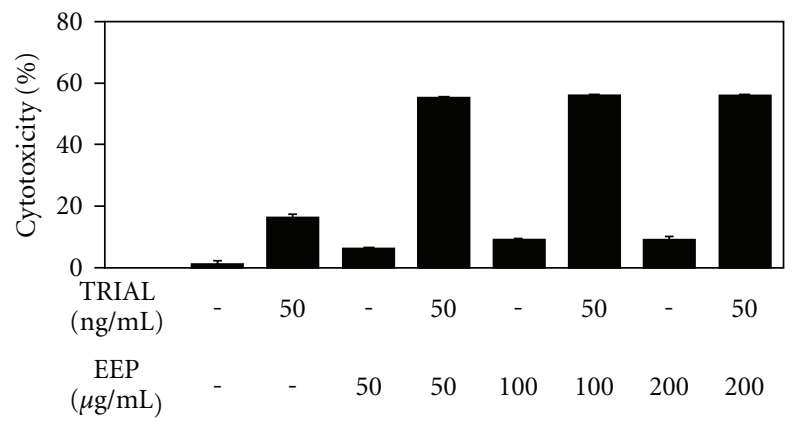

(d)

FIGURE 3: Cytotoxic activity of TRAIL in combination with EEP in prostate cancer cells. The cells: (a) LNCaP and (b) DU145 were incubated for $48 \mathrm{~h}$ with TRAIL at the concentrations of $100 \mathrm{ng} \mathrm{mL}^{-1}$ and with EEP at concentrations of 5-50 $\mu \mathrm{g} \mathrm{mL} \mathrm{m}^{-1}$. The cancer cells: (c) LNCaP and (d) DU145 were incubated for $48 \mathrm{~h}$ with TRAIL at concentrations of $50-200 \mathrm{ng} \mathrm{mL}^{-1}$ and EEP at the concentration of $50 \mu \mathrm{g} \mathrm{mL} \mathrm{L}^{-1}$. The percentage of cell deaths was measured by MTT cytotoxicity assay. The values represent mean \pm SD of three independent experiments performed in quadruplicate $(n=12)$. All differences are statistically significant in relation to control $(P<.05)$.

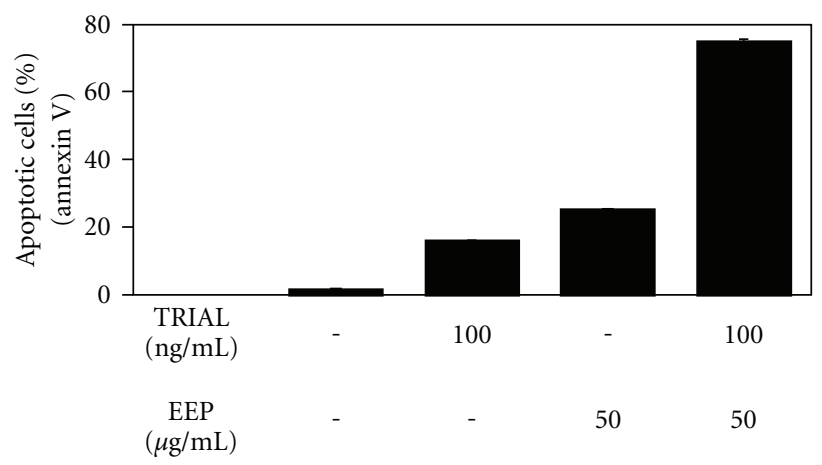

(a)

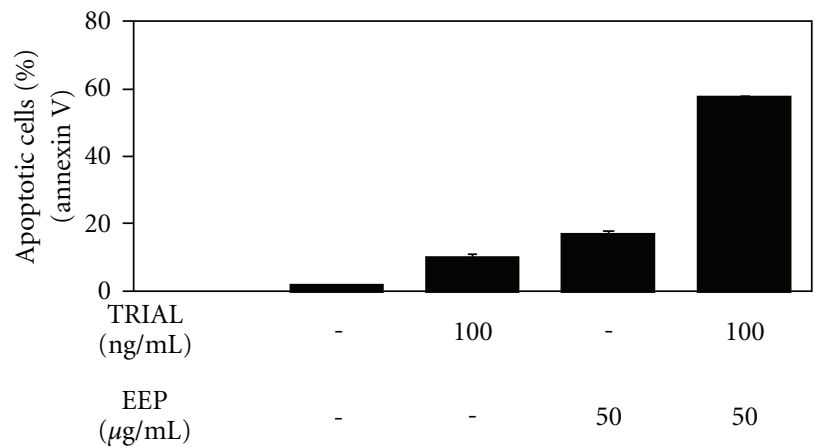

(b)

FIGURE 4: TRAIL induced apoptosis in combination with EEP in prostate cancer cells: (a) LNCaP and (b) DU145. Detection of apoptotic cell death after 48 -h cotreatment with TRAIL at the concentration of $100 \mathrm{ng} \mathrm{mL}^{-1}$ and EEP the concentration of $50 \mu \mathrm{g} \mathrm{mL} \mathrm{m}^{-1}$ by annexin V-FITC staining using flow cytometry. The values represent mean $\pm \mathrm{SD}$ of three independent experiments performed in quadruplicate $(n=12)$. All differences are statistically significant in relation to control $(P<.05)$.

prostate cancer cells. We found that EEP strongly enhanced TRAIL-induced apoptosis in cancer cells. The percentage of apoptotic cells after exposure to $100 \mathrm{ng} \mathrm{mL}^{-1}$ TRAIL in combination with $50 \mu \mathrm{g} \mathrm{mL}^{-1}$ EEP increased to $74.94 \pm$ $0.74 \%$ for LNCaP cells and to $57.39 \pm 0.67 \%$ for DU145 cells. Our results indicated that EEP enhanced apoptosis inducing potential of TRAIL in hormone-sensitivity LNCaP and hormone-refractory DU145 prostate cancer cells. Propolis restored sensitivity of prostate cancer cell lines to TRAILinduced cell death.

The necrotic cell death percentage of prostate cancer cells incubated with TRAIL and/or EEP examined by LDH test was near 0 .

The sequence of drug administration is important to obtain maximum therapeutic benefits in combined therapy. We therefore examined whether cotreatment of prostate 


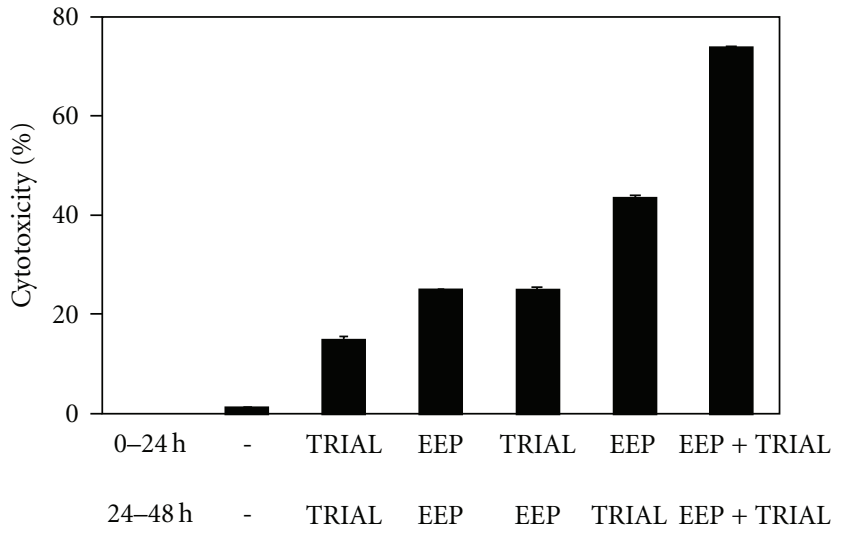

(a)

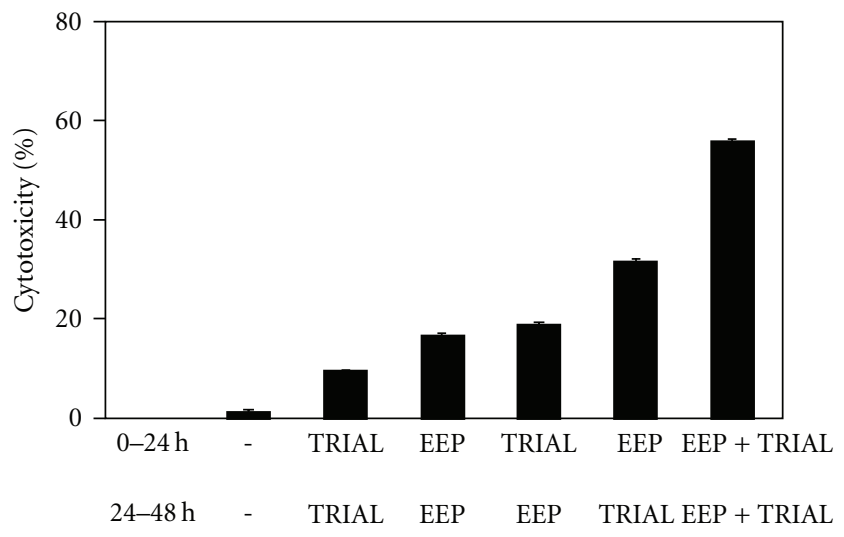

(b)

FIgURE 5: Cytotoxic activity of TRAIL in combination with EEP, after and before exposure to EEP in prostate cancer cells. (a) LNCaP and (b) DU145 cancer cells were as follws: (1) treated with EEP in combination with TRAIL for $48 \mathrm{~h}$; (2) pretreated with EEP for $24 \mathrm{~h}$, followed by TRAIL for another $24 \mathrm{~h}$; and (3) pretreated with TRAIL for $24 \mathrm{~h}$, followed by EEP for another $24 \mathrm{~h}$. The percentage of cell deaths was measured by MTT cytotoxicity assay. The values represent mean \pm SD of three independent experiments performed in quadruplicate $(n=$ 12). All differences are statistically significant in relation to control $(P<.05)$.

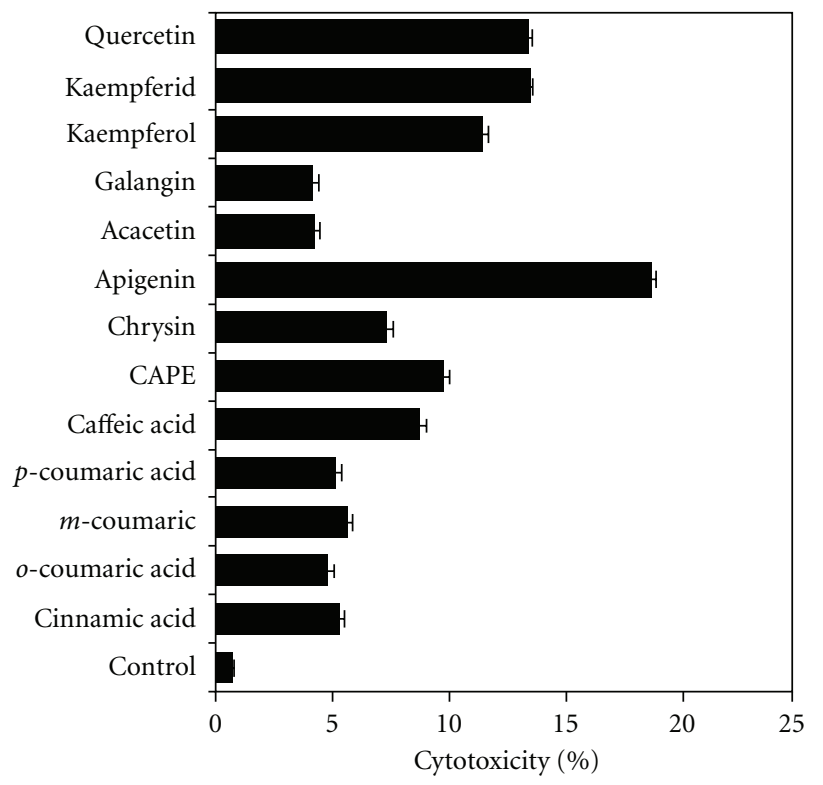

(a)

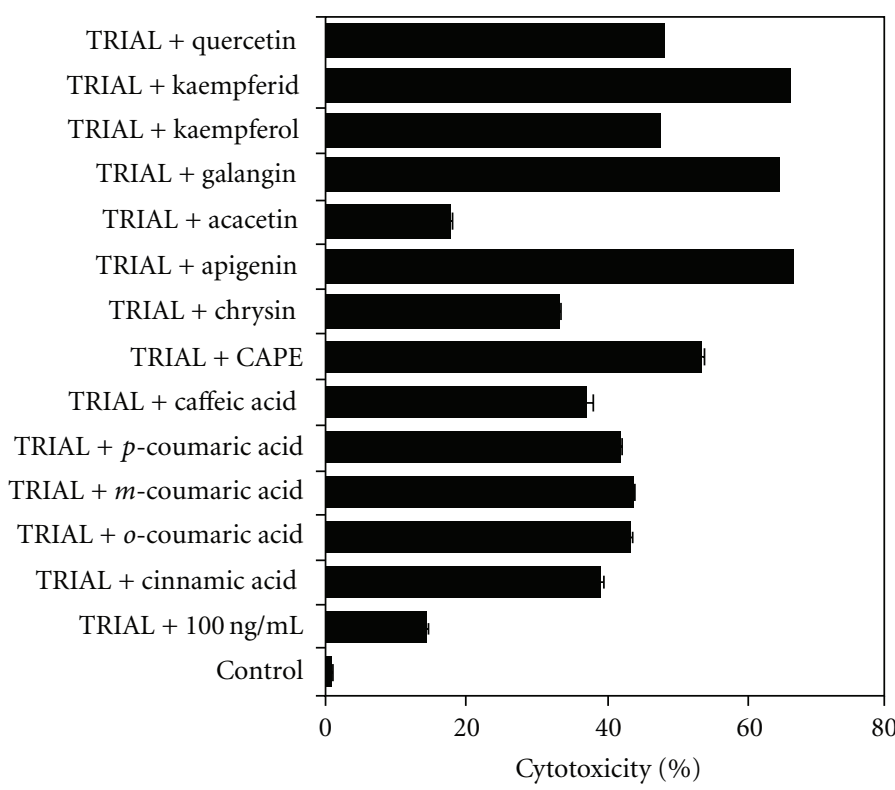

(b)

FIGURE 6: Cytotoxic activity of (a) EEP phenolic components and (b) TRAIL in combination with EEP phenolic components in prostate cancer cells. The LNCaP cells were incubated for $48 \mathrm{~h}$ with phenolic compounds at the concentration of $50 \mu \mathrm{M}$ with or without TRAIL at the concentration of $100 \mathrm{ng} \mathrm{mL}{ }^{-1}$. The percentage of cell deaths was measured by MTT cytotoxicity assay. The values represent mean \pm SD of three independent experiments performed in quadruplicate $(n=12)$. All differences are statistically significant in relation to control $(P<$ $.05)$.

cancer cells with EEP and TRAIL induced greater apoptosis than the concurrent pretreatment with EEP followed by TRAIL and vice versa (Figure 5). Interestingly, the cotreatment of both prostate cancer cell lines with EEP in combination with TRAIL induced greater apoptosis than concurrent pretreatment or single agent alone. Reverse sequence of treatments: pretreatment with EEP followed by TRAIL or pretreatment with TRAIL followed by EEP resulted in significantly lesser apoptosis than in the cotreatment with EEP and TRAIL.

\subsection{Cytotoxicity of Studied Agents in Prostate Cancer Cells}

3.2.1. Phenolic Compounds Detected in Propolis. We investigated the cytotoxic effect on LNCaP cells of 13 phenolic components of propolis: cinnamic acid, $o$-coumaric 


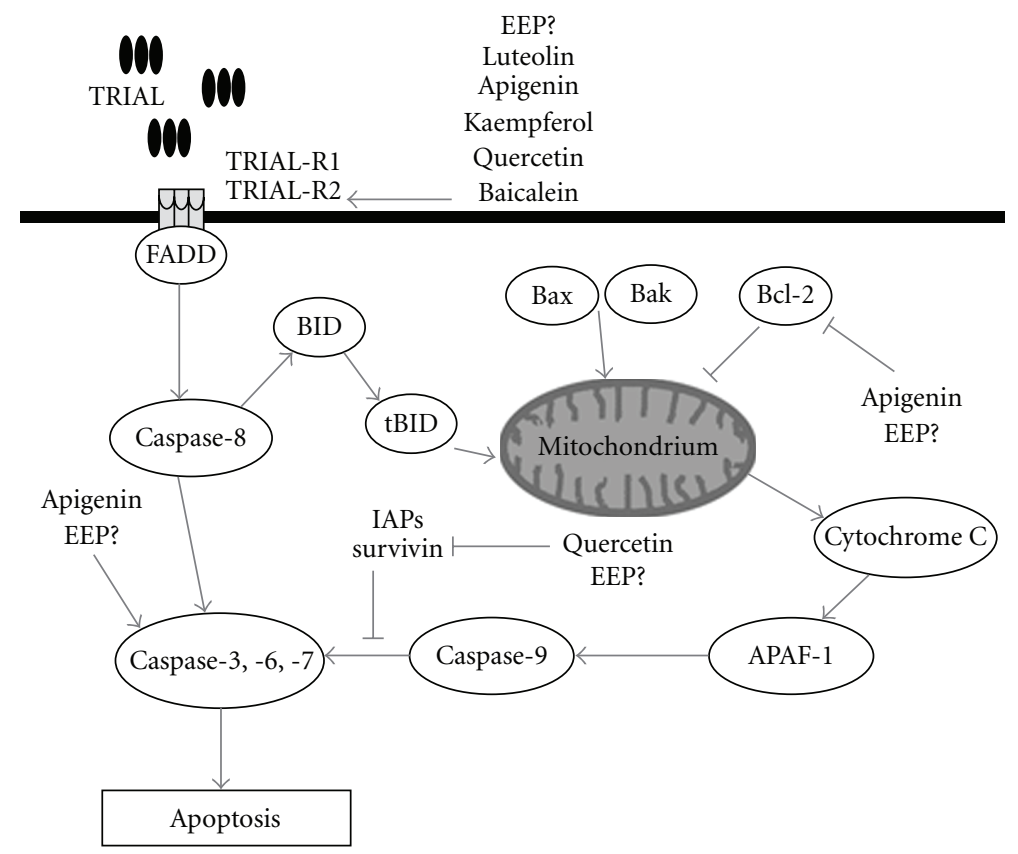

FIGURE 7: The molecular targets of flavonoids in TRAIL apoptosis pathway and the hypothetic impact of EEP in TRAIL-mediated apoptosis in cancer cell. TRAIL binds to death receptors, TRAIL-R1 and/or TRAIL-R2 and promotes the recruitment of adapter molecule FADD (Fasassociated-death domain) to activate caspase- 8 , which trigger activation of downstream effector caspases (caspase-3, -6 and -7). Caspase- 8 mediated also cleavage of Bid (BH3-interacting domain death agonist). Trucated Bid called tBid translocates to the mitochondria where it interacts with Bax (Bcl-2-associated X protein) and Bak (Bcl-2-agonist/killer), stimulating the release oh cytochrome $c$. Antiapoptotic members of Bcl-2 family could inhibit cytochrome $c$ release. Cytochrome $c$ liberated from the mitochondria then binds to the adaptor protein APAF-1 (apoptotic protease-activating factor-1) and procaspase-9, forming the apoptosome and activating caspase-9, which in turn activates executioner caspases (caspase-3, -6 and -7) leading to cell death. Caspase- 9 activity is controlled by IAPs (inhibitor of apoptosis protein) and survivin. Luteolin, apigenin, kaempferol, quercetin and baicalein increase expression of death receptor TRAIL-R2. Apigenin activate executioner caspases and block antiapoptotic Bcl-2 action. Quercetin promotes apoptosis by inhibition of survivin.

acid, $m$-coumaric acid, $p$-coumaric acid, caffeic acid, CAPE, chrysin, apigenin, acacetin, galangin, kaempferol, kaempferid and quercetin (Figure 6(a)). The strongest cytotoxic activity in cancer cells was demonstrated by apigenin (18.76 $\pm 0.65 \%$ cell death). Kaempferol, kaempferid and quercetin induced few cell deaths $(11.42 \pm 0.68,13.44 \pm 0.44$ and $13.36 \pm 0.59 \%$, respectively). The cytotoxicity of other remaining compounds found in propolis in prostate cancer cells was below $10 \%$.

3.2.2. TRAIL in Combination with Phenolic Compounds Detected in Propolis. Cytotoxic effect of TRAIL in combination with phenolic acids or flavonoids in LNCaP cell line measured by MTT assay is shown in Figure 6(b). We tested the effect of a 48 -h cotreatment with TRAIL at the concentration of $100 \mathrm{ng} \mathrm{mL}^{-1}$ together with 13 phenolic components of propolis at the concentration of $50 \mu \mathrm{M}$ on cytotoxicity of prostate cancer cells. The phenolic acids and particularly flavonoids restored TRAIL sensitivity in TRAILresistant LNCaP cells. In our study, apigenin, kaempferid, galangin and CAPE markedly augmented TRAIL mediated cancer cell deaths $(53.51 \pm 0.68-66.06 \pm 0.62 \%)$ and exhibited the strongest cytotoxic effect in combination with TRAIL on LNCaP cells. The other components found in our sample of propolis also increased the percentage of TRAILinduced cell deaths, compared to cytotoxicity of TRAIL alone, but the cytotoxicity was below $50 \%$.

The necrotic cell death percentage of LNCaP cells incubated with TRAIL and/or phenolic components examined by LDH leakage was near 0 .

\section{Discussion}

Epidemiological data support the concept that naturally occurring anticancer agents in the human diet are safe, and nontoxic, and they have long-lasting beneficial effects on human health $[12,21]$. The potential target for complementary and alternative medicine (CAM) research has been on the discovery of natural compounds that can be used in prevention against prostate cancer.

The study by $\mathrm{Li}$ et al. [22] showed that propolis inhibits cellular proliferation and induces apoptosis in prostate cancer cells. In our investigation, we also observed cytotoxic and apoptotic activities of EEP against hormonesensitivity LNCaP and hormone-refractory DU145 prostate cancer cells. Beside antitumor effect, immunomodulatory properties of propolis have been recorded. We investigated the interaction between propolis and tumor necrosis 
factor-related apoptosis inducing ligand on prostate cancer cells. Recombinant human TRAIL used in our study is a soluble protein based on a natural ligand. TRAIL induces programmed death in various cancer cells, in vitro and in vivo [16]. However, some tumor cells are resistant to TRAILmediated cytotoxicity. We and others demonstrated that prostate cancer cell lines, LNCaP and DU145, were resistant to TRAIL-induced apoptosis [17-19].

Our study showed the impact of propolis on the anticancer immune defense. Propolis restores sensitivity of tumor cells to immune effectors mechanisms, such as TRAIL-induced apoptosis in prostate cancer cells. For the first time, our results demonstrated that EEP markedly augmented TRAIL-mediated apoptosis in hormone-sensitivity LNCaP and hormone-refractory DU145 prostate cancer cells. The rapid tumor growth and progression of hormone refractory prostate cancer accounts for most of the morbidity and mortality associated with prostate cancer [1]. The experimental data indicated that propolis is a promising anticancer agent also for the prevention of hormone-refractory prostate cancer.

In the field of CAM, immunomodulation through natural or synthetic substances may be considered as an alternative for the prevention of neoplasm disease. EEP enhances the apoptosis-inducing potential of TRAIL and sensitizes TRAIL-resistant prostate cancer cells. Further investigations will be required to recognize and explain the molecular mechanisms and cellular signaling pathways by which EEP sensitizes cancer cells to TRAIL-induced death. Moreover, due to heterogenous complex composition of propolis, its biological activity is variable. The presence in propolis of so many compounds makes it difficult to know and understand the direct and indirect effects of EEP upon transduction pathway of the signal to TRAIL-mediated apoptosis in cancer cells.

The flavonoids and phenolic components found in propolis are known to affect the apoptosis of prostate cancer cells and may play an important role in cancer chemoprevention $[2,3,23,24]$. We tested in vitro the cytotoxicity of 13 compounds detected in our sample of propolis against prostate cancer. The strongest cytotoxic activity on LNCaP prostate cancer cells was demonstrated by apigenin. Shukla and Gupta $[23,25]$ reported that apigenin in both in vitro and in vivo studies induced apoptosis in prostate cancer.

It has been suggested that phenolic compounds isolated from propolis induce activities of the immune system and exert antitumor effects [9-15, 22-25]. To investigate which compounds found in propolis may be responsible for the enhancement of the apoptosis-inducing potential of TRAIL, we tested the cytotoxic effect of its phenolic components in combination with TRAIL on prostate cancer cells. All detected in our EEP sample compounds used in combination with TRAIL increased the percentage of cell deaths compared to cytotoxicity of TRAIL alone. The phenolic acids and particularly flavonoids restored TRAIL sensitivity in TRAIL-resistant LNCaP prostate cancer cells. In our study, apigenin, kaempferid, galangin and CAPE markedly augmented TRAIL mediated cancer cells death and exhibited the strongest cytotoxic effect in combination with TRAIL on LNCaP cells. Apigenin, kaempferid and galangin, the compounds with the most cytotoxic activity with TRAIL, have three hydroxyl groups (positions 5, 7 and 3 or $4^{\prime}$ ). Every tested flavonoid has hydroxyl groups in fifth and seventh positions. The compounds with only two hydroxyl groups in fifth and seventh positions (chrysin, acacetin), or four (kaempferol) and five hydroxyl groups (quercetin) showed lower cytotoxic activity with TRAIL. The presence of hydroxyl group in position 3 (galangin versus chrysin) decreased activity of galangin, but addition of TRAIL changed this activity. Probably, this activity is dependent on different mechanisms. The position of hydroxyl groups in flavone structure and their number are very important in reaction with reactive oxygen species as well as can influence cytotoxic and apoptotic activities [26, 27].

In study in vitro on $\mathrm{HeLa}$ cell line, we confirmed that EEP sensitize cancer cells to TRAIL-induced apoptosis and two components identified in propolis, apigenin and CAPE, were the most potent agents inducing cell death in combination with TRAIL in HeLa cells [20]. A similar study with flavonoids (Figure7) showed that luteolin, apigenin, kaempferol, baicalein and quercetin synergistically induced apoptosis with TRAIL in human malignant tumor cells [18, 28-33]. Horinaka et al. [28] reported that luteolin increased TRAIL-induced apoptosis in HeLa cells through upregulation of death receptor TRAIL-R2. In other investigation, they also showed the enhanced apoptosis-inducing potential of TRAIL in prostate cancer cell line DU145, leukemic cell line Jurkat, and colon cancer cell line DLD1. The combined use of apigenin and TRAIL caused Bcl-2-interacting domain cleavage, activation of caspases, and increased expression of TRAIL-R2 [18]. Yoshida et al. [29] stated that TRAILR2 upregulation by kaempferol augments TRAIL action in colon cancer cells [29]. Chen et al. [30] showed that suppression of survivin and induction of TRAIL-R2 by quercetin contribute to sensitization of lung cancer cells to TRAIL-induced cytotoxicity. Kim et al. [31] examined the molecular mechanisms by which quercetin augments TRAIL-mediated apoptotic death in prostate cancer cells and confirmed the ability of quercetin to downregulate survivin expression. Taniguchi et al. [32] indicated that baicalein increases TRAIL-R2 expression and overcomes TRAIL resistance in prostate cancer cells.

We demonstrated for the first time that kaempferid, galangin and CAPE enhance the cytotoxic potential of TRAIL in prostate cancer cells. Those polyphenols, beside apigenin, equally firmly sensitize TRAIL-resistant LNCaP cells. The previous study suggested that flavonoids increase expression of TRAIL-R2 [18, 28-30, 32]. We hypothesize that propolis, as one of the richest sources of flavonoids, such as apigenin, kaempferol, kaempferid, galangin, quercetin and CAPE, can influence the expression of death receptor TRAIL$\mathrm{R} 2$, inhibition of antiapoptotic protein (Bcl-2, survivin), or activation of caspases (Figure 7).

We showed that EEP and its phenolic components in vitro augmented TRAIL mediated cell death in prostate cancer, but further study will be required to examine the molecular mechanisms by which EEP and its compounds act 
on cellular signaling pathways and sensitize prostate cancer cells to TRAIL-induced apoptosis. Our findings suggest that the modulation of TRAIL apoptosis pathway may have a significant potential for prostate cancer chemoprevention, and the overcome of TRAIL-resistance by propolis and its phenolic components may be one of the mechanisms responsible for their cancer preventive effects. The obtained results confirmed the significance of EEP and its components in chemoprevention of prostate cancer cells. EEP as a dietary supplement may be useful in chemoprevention agent against prostate cancer.

\section{Funding}

Research Grant 2-164/08 from Medical University of Silesia in Katowice, Poland.

\section{References}

[1] A. Heidenreich, G. Aus, M. Bolla et al., "EAU guidelines on prostate cancer," European Urology, vol. 53, no. 1, pp. 68-80, 2008.

[2] R. P. Singh and R. Agarwal, "Mechanisms of action of novel agents for prostate cancer chemoprevention," EndocrineRelated Cancer, vol. 13, no. 3, pp. 751-778, 2006.

[3] D. N. Syed, Y. Suh, F. Afaq, and H. Mukhtar, "Dietary agents for chemoprevention of prostate cancer," Cancer Letters, vol. 265, no. 2, pp. 167-176, 2008.

[4] E. L. Cooper, "The immune system and complementary and alternative medicine," Evidence-Based Complementary and Alternative Medicine, vol. 4, no. 1, pp. 5-8, 2007.

[5] S. Salvioli, E. Sikora, E. L. Cooper, and C. Franceschi, "Curcumin in cell death processes: a challenge for CAM of age-related pathologies," Evidence-Based Complementary and Alternative Medicine, vol. 4, no. 2, pp. 181-190, 2007.

[6] A. Vojdani and J. Erde, "Regulatory T cells, a potent immunoregulatory target for CAM researchers: modulating allergic and infectious disease pathology (II)," Evidence-Based Complementary and Alternative Medicine, vol. 3, no. 2, pp. 209-215, 2006.

[7] C. Gardana, M. Scaglianti, P. Pietta, and P. Simonetti, "Analysis of the polyphenolic fraction of propolis from different sources by liquid chromatography-tandem mass spectrometry," Journal of Pharmaceutical and Biomedical Analysis, vol. 45, no. 3, pp. 390-399, 2007.

[8] V. S. Bankova, S. S. Popov, and N. L. Marekov, "A study on flavonoids of propolis," Journal of Natural Products, vol. 46, no. 4, pp. 471-474, 1983.

[9] W. Krol, S. Scheller, Z. Czuba et al., "Inhibition of neutrophils' chemiluminescence by ethanol extract of propolis (EEP) and its phenolic components," Journal of Ethnopharmacology, vol. 55, no. 1, pp. 19-25, 1996.

[10] N. Oršolić, A. B. Šaranović, and I. Bašić, "Direct and indirect mechanism(s) of antitumour activity of propolis and its polyphenolic compounds," Planta Medica, vol. 72, no. 1, pp. 20-27, 2006.

[11] S. Scheller, W. Krol, J. Swiacik, S. Owczarek, J. Gabrys, and J. Shani, "Antitumoral property of ethanolic extract of propolis in mice-bearing Ehrlich carcinoma, as compared to bleomycin," Zeitschrift für Naturforschung C, vol. 44, no. 1112, pp. 1063-1065, 1989.

[12] D. F. Birt, S. Hendrich, and W. Wang, "Dietary agents in cancer prevention: flavonoids and isoflavonoids," Pharmacology and Therapeutics, vol. 90, no. 2-3, pp. 157-177, 2001.

[13] C. Chen, M. Weng, C. Wu, and J. Lin, "Comparison of radical scavenging activity, cytotoxic effects and apoptosis induction in human melanoma cells by Taiwanese propolis from different sources," Evidence-Based Complementary and Alternative Medicine, vol. 1, pp. 175-185, 2004.

[14] M. C. Bufalo, J. M. Candeias, and J. M. Sforcin, "In vitro cytotoxic effect of Brazilian green propolis on human laryngeal epidermoid carcinoma (HEP-2) cells," Evidence-Based Complementary and Alternative Medicine, vol. 22, pp. 1-5, 2007.

[15] F. Missima and J. M. Sforcin, "Green Brazilian propolis action on macrophages and lymphoid organs of chronically stressed mice," Evidence-Based Complementary and Alternative Medicine, vol. 5, no. 1, pp. 71-75, 2008.

[16] A. Almasan and A. Ashkenazi, "Apo2L/TRAIL: apoptosis signaling, biology, and potential for cancer therapy," Cytokine and Growth Factor Reviews, vol. 14, no. 3-4, pp. 337-348, 2003.

[17] S. Shankar, T. R. Singh, and R. K. Srivastava, "Ionizing radiation enhances the therapeutic potential of TRAIL in prostate cancer in vitro and in vivo: intracellular mechanisms," Prostate, vol. 61, no. 1, pp. 35-49, 2004.

[18] M. Horinaka, T. Yoshida, T. Shiraishi, S. Nakata, M. Wakada, and T. Sakai, "The dietary flavonoid apigenin sensitizes malignant tumor cells to tumor necrosis factor-related apoptosisinducing ligand," Molecular Cancer Therapeutics, vol. 5, no. 4, pp. 945-951, 2006.

[19] E. Szliszka, J. Bronikowska, A. Majcher, J. Miszkiewicz, and W. Krol, "Enhanced sensitivity of hormone-refractory prostate cancer cells to tumor necrosis factor-related apoptosisinducing ligand (TRAIL) mediated cytotoxicity by taxanes," Central European Journal of Urology, vol. 62, pp. 29-34, 2009.

[20] E. Szliszka, Z. P. Czuba, M. Domino, B. Mazur, G. Zydowicz, and W. Krol, "Ethanolic extract of propolis (EEP) enhances the apoptosis-inducing potential of TRAIL in cancer cells," Molecules, vol. 14, no. 2, pp. 738-754, 2009.

[21] N. Khan, V. M. Adhami, and H. Mukhtar, "Apoptosis by dietary agents for prevention and treatment of cancer," Biochemical Pharmacology, vol. 76, no. 11, pp. 1333-1339, 2008.

[22] H. Li, A. Kapur, J. X. Yang et al., "Antiproliferation of human prostate cancer cells by ethanolic extracts of Brazilian propolis and its botanical origin," International Journal of Oncology, vol. 31, no. 3, pp. 601-606, 2007.

[23] S. Shukla and S. Gupta, "Molecular targets for apigenininduced cell cycle arrest and apoptosis in prostate cancer cell xenograft," Molecular Cancer Therapeutics, vol. 5, no. 4, pp. 843-852, 2006.

[24] K. McEleny, R. Coffey, C. Morrissey, J. M. Fitzpatrick, and R. W. G. Watson, "Caffeic acid phenethyl ester-induced PC-3 cell apoptosis is caspase-dependent and mediated through the loss of inhibitors of apoptosis proteins," BJU International, vol. 94, no. 3, pp. 402-406, 2004.

[25] S. Shukla and S. Gupta, "Apigenin-induced cell cycle arrest is mediated by modulation of MAPK, PI3K-Akt, and loss of cyclin D1 associated retinoblastoma dephosphorylation in human prostate cancer cells," Cell Cycle, vol. 6, no. 9, pp. 11021114, 2007.

[26] Z. P. Czuba and W. Krol, "The importance of hydroxyl substituent in position $4^{\prime}$ in flavonoids for modulation of chemiluminescence generated by an enzymatic system (horseradish peroxidase-luminol-hydrogen peroxide)," Current Topics in Biophysics, vol. 20, pp. 38-41, 1996. 
[27] K. Plochmann, G. Korte, E. Koutsilieri et al., "Structureactivity relationships of flavonoid-induced cytotoxicity on human leukemia cells," Archives of Biochemistry and Biophysics, vol. 460, no. 1, pp. 1-9, 2007.

[28] M. Horinaka, T. Yoshida, T. Shiraishi et al., "The combination of TRAIL and luteolin enhances apoptosis in human cervical cancer HeLa cells," Biochemical and Biophysical Research Communications, vol. 333, no. 3, pp. 833-838, 2005.

[29] T. Yoshida, M. Konishi, M. Horinaka et al., "Kaempferol sensitizes colon cancer cells to TRAIL-induced apoptosis," Biochemical and Biophysical Research Communications, vol. 375, no. 1, pp. 129-133, 2008.

[30] W. Chen, X. Wang, J. Zhuang, L. Zhang, and Y. Lin, "Induction of death receptor 5 and suppression of survivin contribute to sensitization of TRAIL-induced cytotoxicity by quercetin in non-small cell lung cancer cells," Carcinogenesis, vol. 28, no. 10, pp. 2114-2121, 2007.

[31] Y.-H. Kim, D.-H. Lee, J.-H. Jeong, Z. S. Guo, and Y. J. Lee, "Quercetin augments TRAIL-induced apoptotic death: involvement of the ERK signal transduction pathway," Biochemical Pharmacology, vol. 75, no. 10, pp. 1946-1958, 2008.

[32] H. Taniguchi, T. Yoshida, M. Horinaka et al., "Baicalein overcomes tumor necrosis factor-related apoptosis-inducing ligand resistance via two different cell-specific pathways in cancer cells but not in normal cells," Cancer Research, vol. 68, no. 21, pp. 8918-8927, 2008.

[33] E. Szliszka, Z. P. Czuba, K. Jernas, and W. Król, "Dietary flavonoids sensitize HeLa cells to tumor necrosis factor-related apoptosis-inducing ligand (TRAIL)," International Journal of Molecular Sciences, vol. 9, no. 1, pp. 56-64, 2008. 


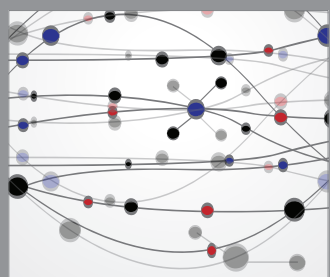

The Scientific World Journal
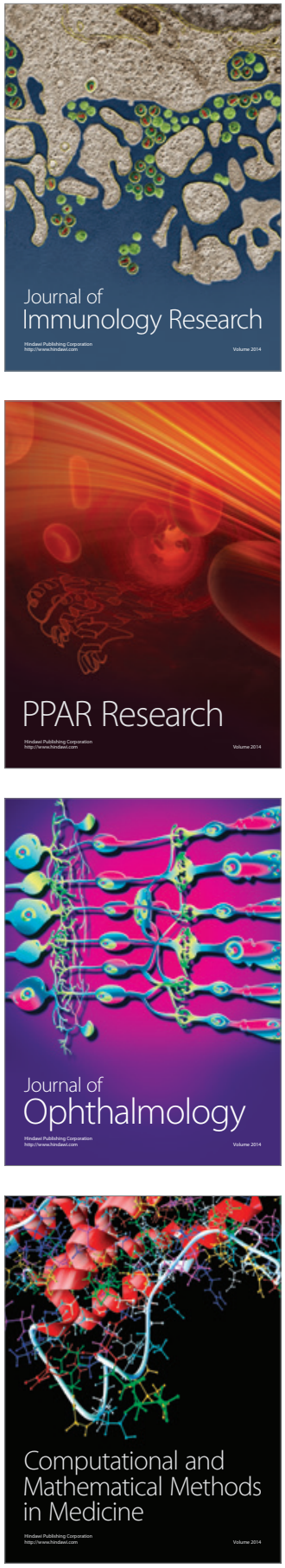

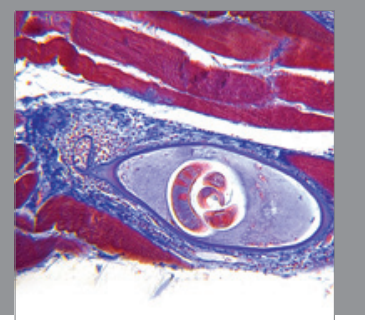

Gastroenterology

Research and Practice
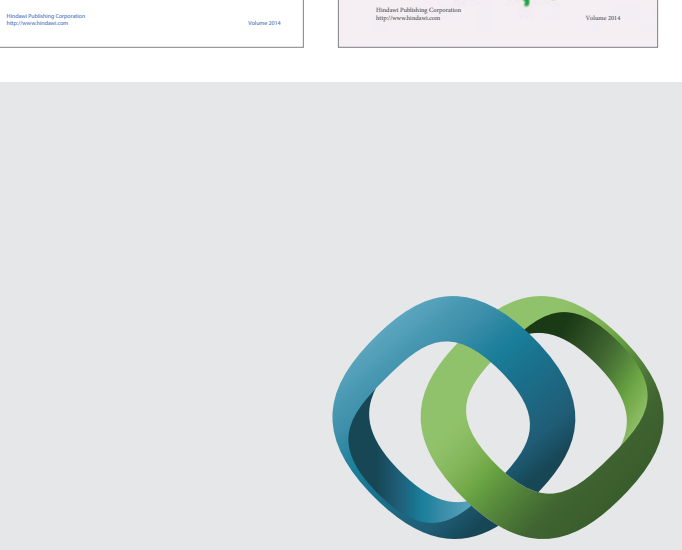

\section{Hindawi}

Submit your manuscripts at

http://www.hindawi.com
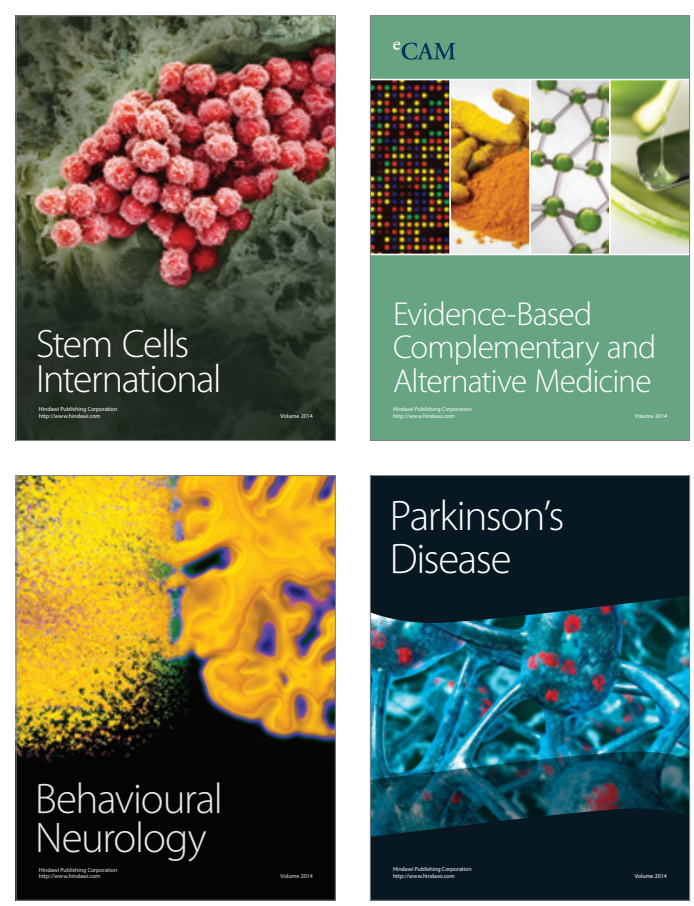

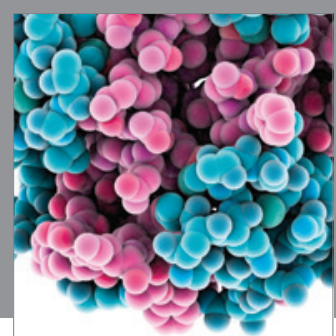

Journal of
Diabetes Research

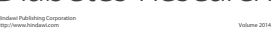

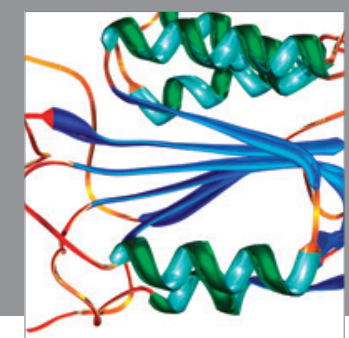

Disease Markers
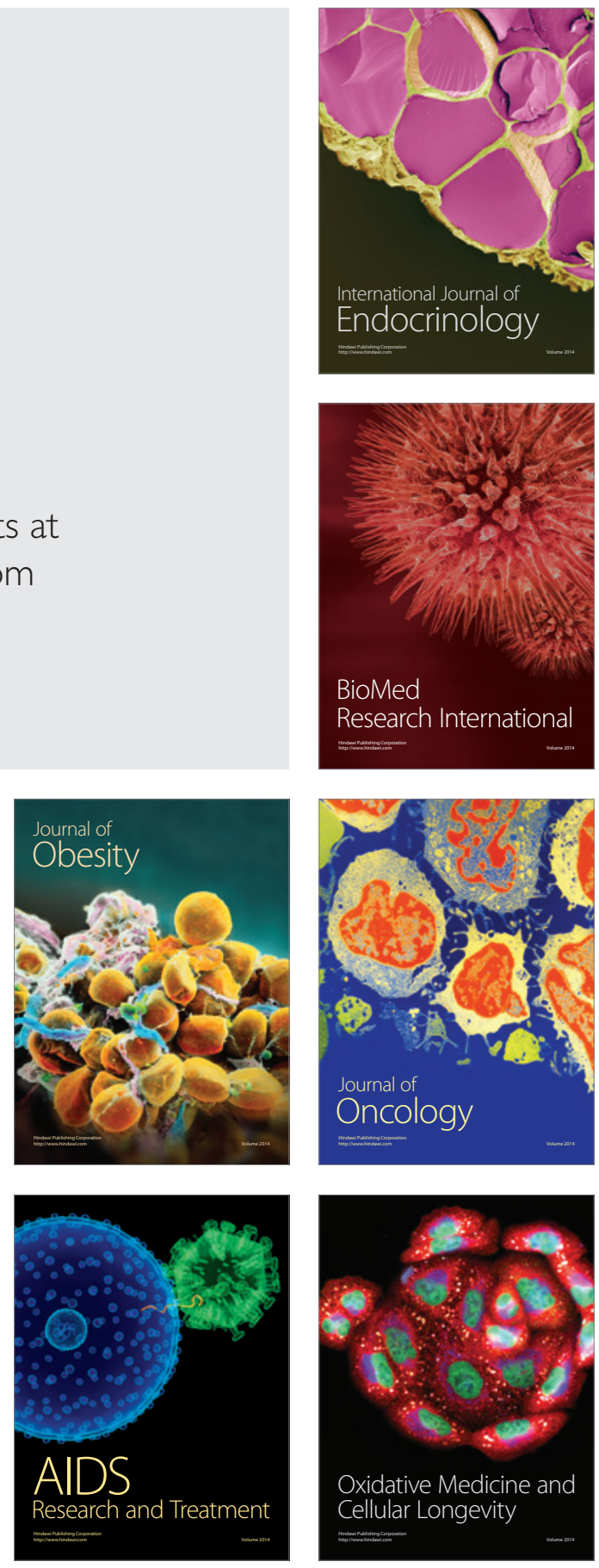